\title{
Genetic Diversity Analysis of Soursop (Annona muricata L.) in West Java Region of Indonesia Using RAPD Markers
}

\author{
A. E. Z. Hasan ${ }^{1^{*}}$, N. Bermawie ${ }^{2}$, H. Julistiono ${ }^{3}$, E. I. Riyanti ${ }^{4}$, Hasim ${ }^{1}$, I. M. Artika ${ }^{1}$ \\ and $P$. Khana ${ }^{1}$ \\ ${ }^{1}$ Department of Biochemistry, Faculty of Mathematics and Natural Sciences, Bogor Agricultural \\ University, Jl. Lingkar Akademik, Kampus IPB Darmaga, Bogor, Indonesia. \\ ${ }^{2}$ Indonesian Spice and Medicinal Crops Research Institute, Indonesian Agency for Agricultural \\ Research and Development, Bogor, Indonesia. \\ ${ }^{3}$ Biology Research Center, Indonesian Institute of Science, Cibinong Bogor, Indonesia. \\ ${ }^{4}$ Molecular Biology Division, Indonesian Center for Agricultural Biotechnology and Genetic Resources, \\ Indonesian Agency for Agricultural Research and Development, Ministry of Agriculture. Indonesia.
}

\section{Authors' contributions}

This work was carried out in collaboration between all authors. All authors read and approved the final manuscript.

Article Information

DOI: $10.9734 / A R R B / 2017 / 34354$

Editor(s):

(1) Gonzalo Emiliano Aranda Abreu, Brain Research Center, Veracruzana University, Veracruz, Mexico.

(2) George Perry, University of Texas at San Antonio, USA.

Reviewers:

(1) Essam Fathy Mohamed El-Hashash, Al-Azhar University, Egypt.

(2) Ashwani Kumar, Shri Ram College Muzaffarnagar, India. Complete Peer review History: http://www.sciencedomain.org/review-history/20113

Original Research Article

Received $24^{\text {th }}$ May 2017 Accepted $29^{\text {th }}$ June 2017 Published $19^{\text {th }}$ July 2017

\section{ABSTRACT}

Aims: The aim of this study was determine the genetic diversity of Annona muricata L. using molecular random amplified polymorphic DNA (RAPD) markers. Amplification of genomic DNA of 9 samples using RAPD analysis yielded 57 fragment, of which 30 were polymorphic, with an average of 6 polymorphic fragment per primer.

Study Design: The data was analysed with SIMQUAL program of NTSYS-pc (Version 2.02), and similarities between accessions were estimated using the Jaccard's coefficient calculated as $\mathrm{J}=\mathrm{A}$ / $(N-D)$, where $A$ is the number of positive matches (that is, presence of band in both samples), $D$ is 
the number of negative matches (that is, absence of band in both samples) and $\mathrm{N}$ is the total sample size including both the number of matches and unmatches. Dendrogram was created from the resultant similarity matrices using the UPGMA method following SAHN function of NTSYS-pc (Version 2.02).

Place and Duration of Study: The study was conducted from September 2014 to March 2015. The analysis of genetic diversity was done in the Biochemistry Laboratory and the Molecular Biology Laboratory of Plant II, Agronomy and Horticulture Faculty of Agriculture Bogor Agricultural University.

Methodology: Plant material from West Java, DNA extraction after that primer screening and DNA amplification. Data analysis and Electrophoresis of amplified product.

Results: The genetic distance was calculated based on Jaccard's similarity coefficient using SIMQUAL program in NTSYS-pc software to clarify the genetic relationships. An UPGMA dendrogram was constructed using NYSYSpc 2.10 software. A clear divergence between the two related species was found from the cluster analysis. Jaccard similarity coefficient of soursop ranged from 0.451 to 0.902 which revealed a wide range of genetic identity. Based on this value it was noticed that the relationship between soursop sample was closely. High similarity coefficient of 0.902 was measured between; the sample GRT3 with CJR2 and CJR3. According to analysis of the Jaccard similarity coefficient, the sample SKB2 with SKB1 had low similarity coefficient (0.451). This indicated that both the accessions were genetically distant.

Conclusion: Primary elected to amplify DNA Annona muricata L. produces two main groups. Group A consists of 4 samples (GRT1, CJR1, SKB1, GRT 2) and group B consisted of 5 samples (GRT3, CJR2, CJR3, SKB2, SKB3).

Keywords: Annona muricata L.; genetic diversity; RAPD; West Java Indonesia.

\section{ABBREVIATIONS}

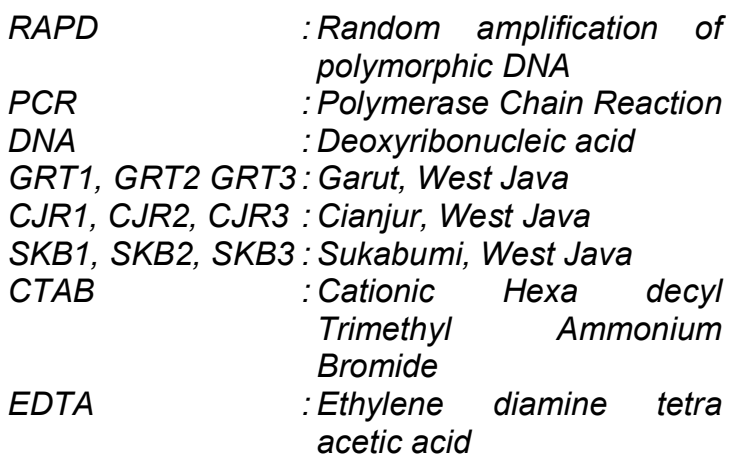

\section{INTRODUCTION}

Soursop (Annona muricata L.) is one type of fruit plants originating from tropical South America, and then spread to the mainland of South Asia and Southeast Asia, including Indonesia. One of the medicinal plants that are currently being developed is Soursop (Annona muricata L.). Compounds in soursop leaves among other steroid / terpenoids, flavonoids, coumarin, alkaloids, and tannins. Flavonoids act as antioxidants for cancer, antimicrobial, antivirus, regulating photosynthesis and plant growth regulators [1,2]. Indonesian people use soursop leaves as an herbal medicine for treating cancer, in particular by drinking boiled water fresh soursop leaves. Soursop leaf is widely used as an herbal medicine for treating various diseases, such as: asthma in the Peruvian Andes, diabetes and seizures in Amozania Peru [3]. Soursop contains acetogenin were able to fight 12 types of cancer cells. The many benefits of soursop make people start switching to consume soursop as an alternative to conventional prevention and treatment [4].

Knowledge of genetic variation is essential for breeding programs because it provides information about the molecular structure of plant genetics, so it can be used as a basis for the selection of crops to be cultivated. Genetic variation can be used as material selection desired sample. Development of the field of molecular DNA analysis these days is often used to characterize genetic variation and relationship in a genus, species, cultivars, or accessions. Information on genetic diversity is the basis for the breeding and population genetics experts in the development and improvement of plants, especially as a first step in the selection of plants. This step is especially important to distinguish between individuals within a species as well as the precise identification of samples and the identification of genes that are potential carriers of a single character. 
RAPD analysis is one method of molecular analysis used to evaluate the genetic relationships populations of organisms. Basic RAPD analysis is the use of PCR machine that is capable of amplifying the DNA sequences in vitro. PCR techniques involving temperature, DNA denaturation, annealing to the DNA, and primer extension by a DNA polymerase enzyme into a fragment of DNA in various sizes [5]. The use of RAPD markers are relatively cheaper, easier, faster results, it does not require knowledge of the background of the genome being analyzed and easily obtain the random primer necessary to analyze the genomes of all kinds of organisms [6].

Based on data obtained from the data Department of Food Crops of West Java province in 2014, is known production centers in West Java's leading commodity soursop plants located in Sukabumi, Cianjur and Garut. Regional differences cause DNA polymorphism or genetic diversity in these plants [7]. The existence of DNA polymorphism in a soursop plant in West Java, especially in the area of production of major commodities soursop has not been identified. Therefore, the research needs to be conducted to determine the genetic pattern of soursop plant in West Java, Indonesia.

\section{MATERIALS AND METHODS}

\subsection{Plant Material and DNA Extraction}

Fresh leafof soursop were collected from the Garut, Cianjur, and Sukabumi district of West Java. This included 9 soursop samples comprising 3 Garut district (GRT1, GRT2 GRT3), 3 Cianjur district (CJR1, CJR2, CJR3), and 3 Sukabumi district (SKB1, SKB2, SKB3). Genomic DNA was isolated from freshly collected young leaves using the CTAB (cetyltrimethyl ammonium bromide) method of [8] with a few modifications. $0.5 \mathrm{~g}$ of young leaf tissue was ground in $2 \%$ Polyvinyl pyrrolidine to fine powder using sterile pestle and mortar and suspended in $700 \mu$ l of preheated $2 \%$ CTAB buffer (2\% CTAB, $0.1 \mathrm{M}$ Tris $\mathrm{pH} 8.0,20 \mathrm{mM}$ EDTA; $1.4 \mathrm{M} \mathrm{NaCl}$, and $1 \% \beta$-mercapto ethanol). The suspension was incubated at $65^{\circ} \mathrm{C}$ for one hour with occasional inversion. An equal volume of chloroform: isoamyl alcohol (24:1 v/v) mixture was added to the suspension and centrifuged at $11,000 \mathrm{rpm}$ for 5 minutes. The aqueous phase was transferred to a new microfuge tube and added with equal volume of chloroform: isoamyl alcohol (24:1) mixture at $10,000 \mathrm{rpm}$ for 15 minutes. The Chloroform: IAA extraction step was repeated twice. The aqueous phase was transferred to a fresh tube containing 0.6 volumes of ice-cold isopropanol. After centrifugation. The pellet was washed in $70 \%$ ethanol and air dried and dissolved in TE buffer (10 mM Tris; 1 mM EDTA, pH 8.0). DNA was quantified using UV-spectrophotometer and diluted to $50 \mathrm{ng} / \mu \mathrm{l}$ and used in PCR.

\subsection{Primer Screening}

Fifteen Operon primers (Operon Technologies Inc., USA) were initially screened using two samples of soursop to determine the suitability of each primer for the study. Five primers were selected for further RAPD-PCR analysis based on their ability to generate clear and distinct polymorphic bands. The primers which generate smeared bands were discarded.

\subsection{DNA Amplification}

PCR reaction was performed as described by [6] with 5 selected primers. Each PCR reaction volume of $20 \mu \mathrm{l}$ contained $2.5 \mathrm{mM} \mathrm{MgCl}$, 250 $\mu \mathrm{MdNTPs}, 1 \mu \mathrm{M}$ of primer, 1 unit of Taq polymerase and $50 \mathrm{ng}$ of genomic DNA. The PCR was performed in thermal cycler of Esco. Amplification conditions were: Initial denaturation at $94^{\circ} \mathrm{C}$ for $5 \mathrm{~min}$ followed by 44 cycles each of denaturation for $1 \mathrm{~min}$ at $94^{\circ} \mathrm{C}$, annealing for 1 $\min$ at $35^{\circ} \mathrm{C}$ and extension for $1 \mathrm{~min}$ at $72^{\circ} \mathrm{C}$ and finally an $8 \mathrm{~min}$ extension at $72^{\circ} \mathrm{C}$.

\subsection{Data Analysis}

For RAPD analysis, the bands were converse to matrix data. In the data matrix, the presence of a band was coded as 1 and absence was marked as 0 , and estimation of similarity among all samples was calculated according to the study of [9]. The data was analysed with SIMQUAL program of NTSYS-pc (Version 2.02), and similarities between accessions were estimated using the Jaccard's coefficient calculated as $\mathrm{J}=$ A / ( N - D), where A is the number of positive matches (that is, presence of band in both samples), $D$ is the number of negative matches (that is, absence of band in both samples) and $\mathrm{N}$ is the total sample size including both the number of matches and unmatches [10]. Dendrogram was created from the resultant similarity matrices using the UPGMA method [11] following SAHN function of NTSYS-pc (Version 2.02) [9]. 


\subsection{Electrophoresis of Amplified Product}

RAPD-PCR product was detected in $1.5 \%$ agarose gel in 1× TAE buffer ( $\mathrm{pH} 8.0,242 \mathrm{~g}$ Tris Base, $57.1 \mathrm{ml}$ glacial acetic acid, 0.5 M EDTA per litre of the buffer) and run in same buffer for 95 minute with voltage at $85 \mathrm{~V}$. Gels were stained with $0.5 \mu \mathrm{g} / \mathrm{ml}$ of ethidium bromide for 20 seconds and washed in distilled water for 15 minutes. DNA profiles were visualized on a UV transilluminator and photographed by using gel documentation system (Alpha imager, USA).

\section{RESULTS AND DISCUSSION}

Nine soursop samples obtained from West Java region were amplified using 5 random primer for RAPD analysis (Table 1). Amplification products of 9 samples yielded a total 57 bands, out of which 30 were found to be polymorphic. The size of the amplification product ranged from 150 to $1000 \mathrm{bp}$. The highest number of bands (15) were obtained with primer OPE-4, while the lowest number of bands (9) were obtained with primer $\mathrm{OPH}-13$. The percentage of polymorphism ranged from 40 to $81.82 \%$. Primer OPE-19, revealed the highest polymorphism (81.82\%) while primer OPE-4 exhibited the lowest polymorphism (40\%).

The primer OPE-4 showed 9 monomorphic bands were in the range of $200 \mathrm{bp}$ to $1500 \mathrm{bp}$ (Fig. 1). The primer OPE-7 has amplified a total number of 11 bands in the ranges from $250 \mathrm{bp}$ to $1100 \mathrm{bp}$. The primer OPH-5 generated 1 polymorphic bands of size 2400bp while 1 band was absent in GRT1, GRT2, CJR1, SKB1, and present in the other samples. A band size of 1100bp was absent in GRT2 and SKB1, while present in the other 7 samples. The primer OPH19 showed 2 monomorphic bands and 9 polymorphic bands were in the range of $300 \mathrm{bp}$ to $1300 \mathrm{bp}$. In the case of primer OPH-13 it amplified a total number of 9 bands. All the 9 samples reveal monomorphic and polymorphic bands ranged from $\sim 200 \mathrm{bp}$ to $1400 \mathrm{bp}$.

A dendrogram (Fig. 2) based on UPGMA analysis grouped the 9 samples into 2 main groups, with similarity coefficient ranging from 0.60 to 0.94 . The dendrogram obtained 2 main groups (A and B) with 4 and 5 samples respectively. The main groups A has 2 clusters (I and II). Cluster I has GRT1, CJR1 and SKB1. Clusters II contained GRT2. The main groups B with clusters I has GRT3, CJR2, CJR3 and SKB 3. Clusters II from main group B contained SKB2.

The genetic distance was calculated based on Jaccard's similarity coefficient using SIMQUAL program in NTSYS-pc software to clarify the genetic relationships (Table 2, similarity with Nei's index [9]). An UPGMA dendrogram was constructed using NYSYSpc 2.10 software. A clear divergence between the two related species was found from the cluster analysis. Jaccard similarity coefficient of soursop ranged from 0.451 to 0.902 which revealed a wide range of genetic identity. Based on this value it was noticed that the relationship between soursop sample was closely. High similarity coefficient of 0.902 was measured between; the sample CJR2 with GRT3 and CJR3 with GRT3. According to analysis of the Jaccard similarity coefficient, the sample SKB2 with SKB1 had lowest value of similarity coefficient $(0.451)$. This indicated that both the accessions were genetically distant.

Based on the genetic diversity, known that GRT2 has a genotype that is most different from the others. Results of RAPD marker analysis illustrate that GRT1 and GRT3 equally in the region have a different genotype. Although the samples taken are in one district, but the genetic diversity can produce a large diversity. It is affected because the specific environment in each region.

Table 1. Details of amplification obtained with different RAPD primers

\begin{tabular}{lllllll}
\hline No & $\begin{array}{l}\text { Name of } \\
\text { primer }\end{array}$ & Sekuen (5'-3') & $\begin{array}{l}\text { No. of } \\
\text { total } \\
\text { bands }\end{array}$ & $\begin{array}{l}\text { No. of } \\
\text { polymorphic } \\
\text { bands }\end{array}$ & $\begin{array}{l}\text { Polymorphism } \\
\text { percent (\%) }\end{array}$ & $\begin{array}{l}\text { Total no. } \\
\text { of bands } \\
\text { amplified }\end{array}$ \\
\hline 1 & OPE4 & GTGACATGCC & 15 & 6 & 9 & 40.00 \\
2 & OPE7 & AGATGCAGCC & 11 & 6 & 5 & 54.55 \\
3 & OPH5 & AGTCGTCCCC & 11 & 5 & 6 & 45.45 \\
4 & OPH13 & TGTAGCTGGG & 9 & 4 & 5 & 44.44 \\
5 & OPH19 & GTGACCAGCC & 11 & 9 & 3 & 81.82 \\
\multicolumn{1}{l}{ Total } & & & $\mathbf{5 7}$ & $\mathbf{3 0}$ & $\mathbf{2 8}$ & $\mathbf{5 2 . 6 3}$ \\
\hline
\end{tabular}



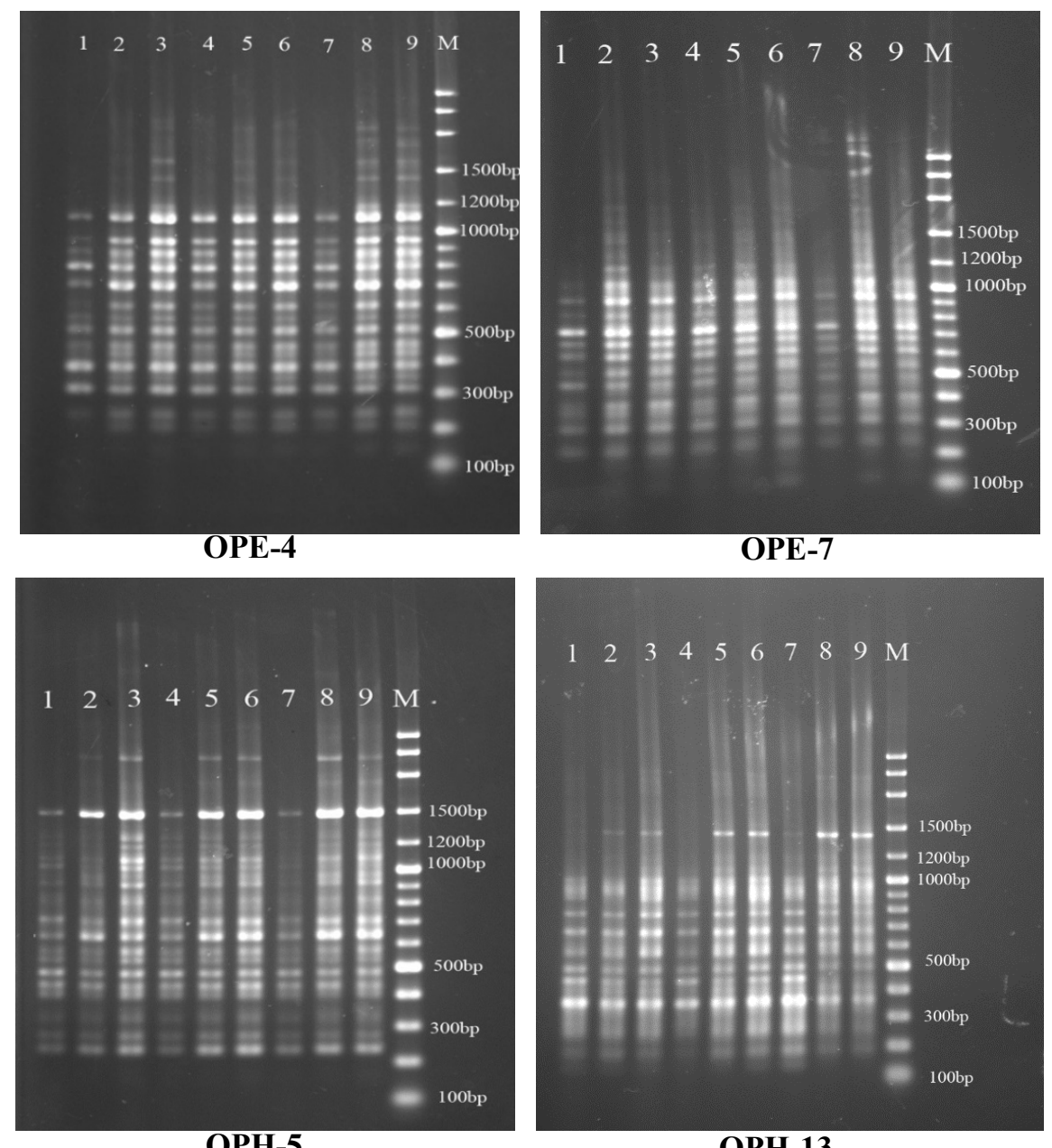

OPH-5

OPH-13

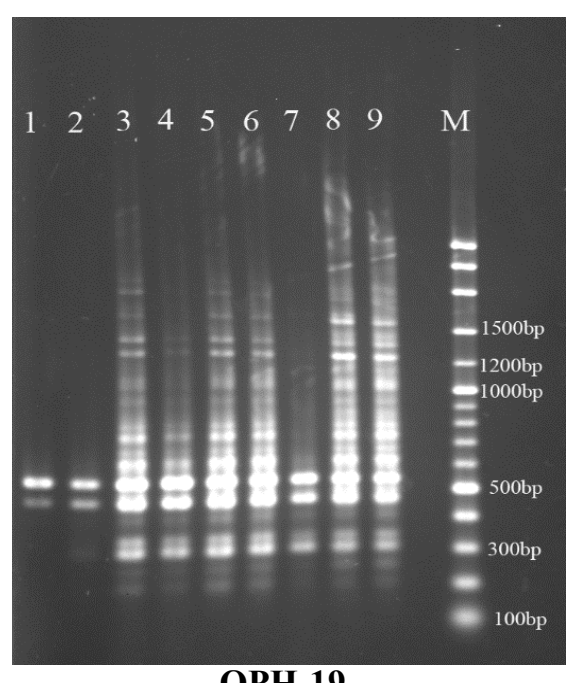

OPH-19

Fig. 1. RAPD profile of 9 soursop sample from 5 primer. From left to right, Garut 1-3 (GRT1, GRT2, GRT3), Cianjur 5-6 (CJR1, CJR2, CJR3), Garut 7-9 (GRT1, GRT2, GRT3), M is DNA marker 


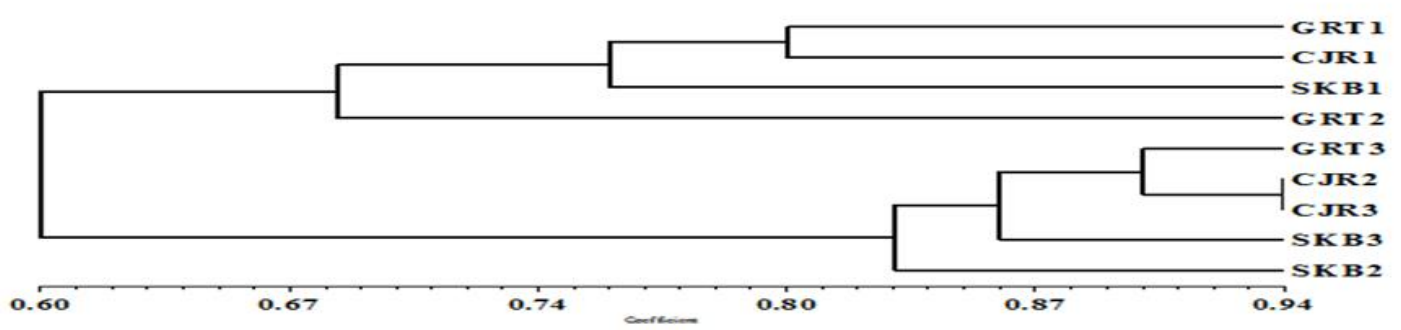

Fig. 2. Dendrogram of 9 sampels based on RAPD analysis

Table 2. The similarity coefficient by Jaccard in NTSYSpc 2.10e software for 9 sample of soursop

\begin{tabular}{llllllllll}
\hline & GRT1 & GRT2 & GRT3 & CJR1 & CJR2 & CJR3 & SKB1 & SKB2 & SKB3 \\
\hline GRT1 & 1.000 & & & & & & & & \\
GRT2 & 0.686 & 1.000 & & & & & & & \\
GRT3 & 0.569 & 0.725 & 1.000 & & & & & & \\
CJR1 & 0.804 & 0.686 & 0.706 & 1.000 & & & & & \\
CJR2 & 0.529 & 0.686 & 0.902 & 0.686 & 1.000 & & & & \\
CJR3 & 0.529 & 0.686 & 0.902 & 0.686 & 0.941 & 1.000 & & & \\
SKB1 & 0.765 & 0.686 & 0.549 & 0.745 & 0.569 & 0.608 & 1.000 & & \\
SKB2 & 0.471 & 0.647 & 0.804 & 0.627 & 0.843 & 0.824 & 0.451 & 1.000 & \\
SKB3 & 0.510 & 0.608 & 0.843 & 0.667 & 0.882 & 0.863 & 0.490 & 0.863 & 1.000 \\
\hline
\end{tabular}

RAPD has been widely used for various purposes such as studying genetic diversity in turmeric and ginger [12], Ganoderma spp. [13], turmeric [12], Xylocarpus spp [14], date palm [15], fig Tunisia barbary [16], cherry [17], almonds [18].

\section{CONCLUSION}

Primary elected to amplify DNA Annona muricata $\mathrm{L}$. produces two main groups. Group A consists of 4 samples (GRT1, CJR1, SKB1, GRT2) and group B consisted of 5 samples (GRT3, CJR2, CJR3, SKB2, SKB3).

\section{ACKNOWLEDGEMENTS}

The authors are grateful to Department of Biochemistry, Faculty of Mathematics and Natural Sciences, Bogor Agricultural University and financial support from Indonesian Agency for Agricultural Research and Development, Ministry of Agriculture.

\section{COMPETING INTERESTS}

Authors have declared that no competing interests exist.

\section{REFERENCES}

1. Hasan AEZ, Mangunwidjaja D, Sunarti TC, Suparno O, Setiyono A. Investigating the antioxidant and anticytotoxic activities of propolis collected from five regions of Indonesia and their abilities to induce apoptosis. Emir J Food Agric. 2014;26(5):390-8.

2. Robinson T. Kandungan Organik Tumbuhan Tinggi Edisi VI. Bandung (ID): ITB. Indonesian; 1995.

3. Zuhud E. Bukti Kedahsyatan Sirsak Menumpas Kanker. Jakarta (ID): Agromedia Pustaka. Indonesian; 2011.

4. Adjie S. Dahsyatnya Sirsak Tumpas Penyakit. Jakarta (ID): Pustaka Bunda. Indonesian; 2011.

5. Weising $\mathrm{K}$, Nybom $\mathrm{H}$, Wolff $\mathrm{K}$, Meyer W. DNA Finger printing in plants and fungi. Boca Raton: CRC Press; 1995.

6. Tingey SV, Rafalski JA, Williams JGK. Genetic analysis with RAPD markers. Application of RAPD technology to plant breeding. Joint plant breeding symposia series; 1992 Nov 1; Minneapolis, Minnesota. Minneapolis (MN): American Genetic Association; 1992. 
7. Hutter S, Viella AJ, Rozas J. Genome-wide DNA polymorphism analyses using Vari Scan. BMC Bioinform. 2006;7:1-10.

8. Doyle JJ, JL Doyle. A rapid total DNA preparation procedure for fresh plant tissue. Focus. 1990;12:13-15.

9. Nei M, Li WH. Mathematical model for studying genetic variation in terms of restriction endonucleases. Proc. Natl. Acad. Sci. 1979;76:5269-5273.

10. Rohlf FJ. NTSY Spc: Numerical taxonomy and multivariate analysis system version 2.0 user guide. Applied Biostatistics Inc; 1998.

11. Sokal RR, Sneath PHA. Principles of numerical taxonomy. Freeman San Francisco. 1963;359.

12. Utami A. Analisis polimorfisme DNA tanaman kunyit (Curcuma longa L.) dan temulawak (Curcuma xanthorrhiza Roxb) local menggunakan marka RAPD [skirpsi]. Bogor (ID): Institut Pertanian Bogor. Indonesian; 2012.

13. Palupi DLN. Analisis keragaman genetic Ganoderma spp. Menggunakan penanda molekuler random amplified polymorphic DNA (RAPD) [skripsi]. Bogor (ID): Institut Pertanian Bogor. Indonesian; 2010.
14. Umesh RP, Jitha B, I. Paul A, Rajaram P. Genetic variation between Xylocarpus spp. (Meliaceae) as revealed by Random Amplified Polymorphic DNA (RAPD) markers. Emir J Food Agric. 2013;25(8):597-604.

15. Srivashtav VS, Kapadia CV, Mahatma MK, Jha SK, Jha S, T Ahmad. Genetic diversity analysis of date palm (Phoenix dactylifera L.) in the Kutch region of India using RAPD and ISSR markers. Emir J Food Agric. 2013;25(11):907-914.

16. Bendhifi M, Ghada B, Lazhar Z, Sami S, Amel SH. Assessment of genetic diversity of Tunisian Barbary Fig (Opuntaficus indica) cultivars by RAPD markers and morphological traits. Sci Hort. 2013;158:17.

17. Cai YZ, Gui FZ, Dong WC. Studies on genetic variation in wild cherry using RAPD analysis. Sodininkyste. 2006;25(3):302315.

18. Sharma D, Rajinder K, Krishan K, Satyavrat B. Genetic Diversity among selected samples of almond Prunusdulcis Miller DA. Webb assessed by random amplified polymorphic DNA (RAPD) markers. AJB. 2012;11(83):14877-14883.

(c) 2017 Hasan et al.; This is an Open Access article distributed under the terms of the Creative Commons Attribution License (http://creativecommons.org/licenses/by/4.0), which permits unrestricted use, distribution, and reproduction in any medium, provided the original work is properly cited.

Peer-review history:

The peer review history for this paper can be accessed here: http://sciencedomain.org/review-history/20113 